\title{
Pengaruh model discovery learning terhadap prestasi belajar fisika siswa kelas X SMAN 02 Batu
}

\author{
Debora Febbivoyna, Sumarjono*, Bambang Tahan Sungkowo \\ Universitas Negeri Malang, Jl. Semarang No. 5 Malang, Jawa Timur, Indonesia \\ *Penulis korespondensi, Surel: sumarjono.fmipa@um.ac.id
}

Paper received: 01-07-2021; revised: 15-07-2021; accepted: 31-07-2021

\begin{abstract}
Abstrak
Penelitian ini dilaksanakan dengan tujuan untuk mengetahui pengaruh model pembelajaran Discovery Learning terhadap prestasi belajar fisika. Model pembelajaran Discovery Learning termasuk level pertama dari Levels of Inquiry merupakan model pembelajaran yang membuat siswa aktif menemukan konsep fisika serta mengkonstruksi sendiri pengetahuannya. Melalui model pembelajaran Discovery Learning, siswa mampu menguasai konsep fisika dan mampu meningkatkan prestasi belajarnya. Hasil analisis data menunjukkan nilai rata-rata prestasi belajar fisika siswa yang dibelajarkan dengan model pembelajaran Discovery Learning sebesar 3,06, sedangkan nilai rata-rata prestasi belajar fisika siswa yang dibelajarkan dengan cara konvensional adalah 2,77. Kesimpulan penelitian ini adalah: 1) Prestasi belajar fisika siswa yang dibelajarkan dengan model pembelajaran Discovery Learning lebih tinggi dari pada siswa yang dibelajarkan secara konvensional. 2) Model pembelajaran Discovery Learning berpengaruh terhadap prestasi belajar fisika siswa kelas X SMAN 02 Batu.
\end{abstract}

Kata kunci: discovery learning; prestasi belajar fisika

\section{Pendahuluan}

Saat ini, pemerintah sedang melaksanakan Kurikulum 2013. Kegiatan pembelajaran dalam Kurikulum 2013 dilaksanakan dengan pendekatan saintifik yaitu mengamati, menanya, mencoba, menalar/ mengasosiasi, dan mengomunikasikan (Kemdikbud, 2013). Berdasarkan Peraturan Menteri Pendidikan dan Kebudayaan No. 59 tahun 2014 tentang Kerangka Dasar dan Struktur Kurikulum, terdapat beberapa penyempurnaan pola pikir dalam Kurikulum 2013. Penyempurnaan pola pikir tersebut adalah: (1) Penguatan pola pembelajaran yang berpusat pada peserta didik. Peserta didik harus memiliki pilihan-pilihan terhadap materi yang dipelajari dan gaya belajarnya (learning style) untuk memiliki kompetensi yang sama. (2) Penguatan pola pembelajaran interaktif (interaktif guru-peserta didik-masyarakat-lingkungan alam, sumber/ media lainnya). (3) Penguatan pembelajaran aktif mencari pengetahuan. (4) Penguatan pola belajar sendiri dan kelompok. (5) Penguatan pola pembelajaran kritis.

Salah satu pola pembelajaran Kurikulum 2013 adalah siswa aktif mencari pengetahuan. Hal ini sesuai dengan hakikat pembelajaran fisika. Fisika harus dipandang sebagai proses dan produk (Collette dan Chiapetta, 1994). Proses yang dimaksud adalah cara berpikir (a way of thinking) dan cara menyelidiki (a way of investigating). Sejalan dengan hal tersebut, Kurikulum 2013 menghendaki siswa melalui proses ilmiah untuk mempelajari pengetahuan. Siswa diharapkan dapat membangun sendiri pengetahuan yang ada dalam benaknya, mencari dan menemukan sendiri makna segala sesuatu yang dipelajari.

Menurut Trianto (2009), sebagian besar pola pembelajaran fisika masih bersifat transmisif, pengajar mentransfer dan memberikan konsep-konsep secara langsung pada siswa. Dalam pandangan ini, siswa secara pasif 'menyerap' struktur pengetahuan yang 
diberikan guru atau yang terdapat dalam buku pelajaran. Pembelajaran hanya sekedar penyampaian fakta, konsep, prinsip, dan keterampilan kepada siswa. Penumpukan informasi/konsep pada siswa dapat saja kurang bermanfaat apabila hanya dikomunikasikan oleh guru kepada subjek didik melalui satu arah seperti menuang air ke dalam gelas. Transfer pengetahuan saja akan berdampak pada hasil pemahaman siswa yang kurang sistematik dan komprehensif (Wenning, 2010). Penumpukan informasi yang seringkali kurang bermakna dan kurang dipahami siswa inilah yang dapat mengakibatkan rendahnya prestasi belajar fisika siswa.

Berdasarkan hasil observasi, prestasi belajar fisika siswa kelas X MIA SMAN 02 Batu masih perlu ditingkatkan. Data tes ulangan harian fisika menunjukkan masih banyak siswa yang belum mendapatkan nilai tuntas. Berdasarkan Permendikbud No $81 \mathrm{~A}$, nilai ketuntasan minimal untuk seluruh kompetensi dasar pada kompetensi pengetahuan dan kompetensi keterampilan yaitu 2.66 (B-). Untuk KD pada KI-3 dan KI-4, seorang peserta didik dinyatakan sudah tuntas belajar untuk menguasai KD yang dipelajarinya apabila menunjukkan indikator nilai $\geq 2.66$ dari hasil tes formatif. Namun dari empat kelas yaitu kelas X MIA 1, 2, 3, dan 4 rata-rata hanya $50 \%$ saja siswa di tiap kelas yang mendapatkan nilai di atas 2,67 pada saat ulangan harian. Hal ini menunjukkan bahwa prestasi belajar fisika siswa kelas X SMAN 02 Batu masih perlu ditingkatkan.

Salah satu solusi yang diduga mampu meningkatkan prestasi belajar fisika siswa adalah diterapkannya model Discovery Learning. Model Discovery Learning adalah model pembelajaran yang mengarah pada kegiatan-kegiatan yang membangun suatu konsep oleh siswa (Wenning, 2005). Pembelajaran dengan Discovery Learning dapat membantu siswa mengembangkan pemahaman konseptual berdasarkan pengalaman dasar siswa (Wenning, 2010). Dengan menggunakan model pembelajaran ini, diharapkan siswa dapat menguasai konsep fisika sehingga dapat meningkatkan prestasi belajarnya.

\section{Metode}

Penelitian ini termasuk penelitian quasy experiment dengan rancangan eksperimen Posttest Only Control Group Desain (Sugiyono, 2012:76). Penelitian ini memberikan perlakuan pada dua kelas, yaitu kelas eksperimen dan kelas kontrol. Kelas eksperimen dibelajarkan dengan model pembelajaran Discovery Learning sedangkan kelas kontrol dibelajarkan dengan cara konvensional. Populasi dalam penelitian ini adalah seluruh kelas X MIA SMAN 02 Batu yaitu siswa kelas X MIA 1, X MIA 2, X MIA 3, dan X MIA 4 tahun ajaran 2014/2015. Sampel yang digunakan adalah kelas X MIA-4 sebagai kelas eksperimen dengan jumlah siswa 31 orang dan kelas X MIA-2 sebagai kelas kontrol dengan jumlah siswa 34 orang.

Sebelum dilakukan analisis data, dilakukan uji persyaratan analisis pada data skor post test diuji. Uji persyaratan analisis data dilakukan dengan uji normalitas menggunakan uji chi kuadrat dan uji homogenitas varians menggunakan uji kesamaan dua varian. Setelah itu dilakukan uji hipotesis ini menggunakan uji-t untuk mengetahui perbedaan prestasi belajar fisika antara siswa yang dibelajarkan dengan model pembelajaran Discovery Learning dan siswa yang belajar secara konvensional. Selanjutnya untuk mengetahui kelas yang memiliki prestasi belajar fisika yang lebih tinggi dapat diketahui dengan membandingkan rata-rata skor post test antara kelas eksperimen dan kelas kontrol. 


\section{Hasil dan Pembahasan}

\subsection{HASIL}

Pembelajaran dengan model Discovery Learning dilaksanakan sesuai dengan sintaks pembelajaran menurut Wenning (2011), yaitu (1) observation, (2) manipulation, (3) generalization, (4) verification, dan (5) application. Berdasarkan hasil observasi kegiatan pembelajaran, diperoleh rata-rata persentase keterlaksanaan pembelajaran di setiap pertemuan adalah $86,57 \%$. Pada pertemuan pertama, keterlaksanaan sintaks Discovery Learning adalah 81\%. Pada pertemuan kedua, keterlaksanaan sintaks Discovery Learning adalah 84\%. Pada pertemuan ketiga, keterlaksanaan sintaks Discovery Learning 89,3\%. Pada pertemuan keempat, keterlaksanaan sintaks Discovery Learning adalah 92\%. Data tersebut menunjukkan terjadi peningkatan keterlaksanaan sintaks di setiap pertemuan.

Setelah diberi perlakuan berupa model pembelajaran Discovery Learning pada kelompok eksperimen dan cara pembelajaran konvensional pada kelompok kontrol, maka dilakukan post test. Skor post test kedua kelas ditunjukkan pada Tabel 1 sebagai berikut.

Tabel 1. Deskripsi Data Post Test

\begin{tabular}{lll}
\hline Parameter & Kelas Eksperimen & Kelas Kontrol \\
\hline $\mathbf{N}$ & 31 & 34 \\
\hline$\overline{\boldsymbol{X}}$ & 3,06 & 2,77 \\
\hline $\boldsymbol{X}_{\text {min }}$ & 2,00 & 2,00 \\
\hline $\boldsymbol{X}_{\text {maks }}$ & 3,80 & 3,60 \\
\hline $\mathbf{S d}$ & 0,3893 & 0,4053 \\
\hline
\end{tabular}

Berdasarkan Tabel 1, prestasi belajar fisika kelas eksperimen memiliki rata-rata post test 3,06, sedangkan pada pembelajaran kelas kontrol memiliki rata-rata post test 2,77. Hasil uji normalitas dengan uji Chi Kuadrat diperoleh nilai $\chi^{2}$ hitung $=4,416<9,488$ $\left(\chi^{2} 63 ; 05\right)$ pada kelompok siswa yang belajar dengan model pembelajaran Discovery Learning dan $\chi^{2}$ hitung $=6,505<7,815\left(\chi^{2} 63 ; 05\right)$ pada kelompok siswa yang belajar secara konvensional. Hal ini berarti bahwa kedua data pada skor post test tersebut berdistribusi normal. Hasil uji homogenitas varians dengan uji kesamaan dua varians diperoleh nilai $\mathrm{F}_{\text {hitung }}=1,083<1,795\left(\mathrm{~F}_{33 ; 30 ; 05}\right)$. Hal ini berarti bahwa kedua data pada skor post test tersebut memiliki varians yang homogen.

Selanjutnya, hasil uji hipotesis dengan uji-t untuk kelas eksperimen dan kontrol dapat dilihat pada Tabel 2 .

Tabel 2. Hasil Uji-t Post Test Kelas Eksperimen dan Kelas Kontrol

\begin{tabular}{llllll}
\hline $\begin{array}{l}\text { Sumber } \\
\text { Varians }\end{array}$ & $\begin{array}{l}\text { Jumlah Kuadrat } \\
\text { Rata Rata } \\
(\mathrm{JK})\end{array}$ & $\begin{array}{l}\text { Derajat } \\
\text { Kebebasan } \\
(\mathrm{db})\end{array}$ & $\begin{array}{l}\text { Taraf } \\
\text { Signifikansi }\end{array}$ & \multirow{2}{*}{$\mathrm{t}_{\text {hitung }}$} & \multirow{2}{*}{$\mathrm{t}_{\text {tabel }}$} \\
\cline { 1 - 4 } Eksperimen & 4,547 & 63 & 0.05 & 2,948 & 1,998 \\
\cline { 1 - 3 } Kontrol & 5,421 & 63 & 0.05 & & \\
\hline
\end{tabular}


Berdasarkan Tabel 2 dapat dilihat bahwa hasil uji-t menunjukkan nilai $\mathrm{t}_{\text {hitung }}=2,948>1,998\left(\mathrm{t}_{63 ; 05}\right)$.

\subsection{PEMBAHASAN}

Berdasarkan hasil post test menunjukkan adanya perbedaan skor rata-rata pada kelompok siswa yang belajar dengan menggunakan model pembelajaran Discovery Learning dan siswa yang belajar dengan cara pembelajaran konvensional. Skor rata-rata post test pada kelompok siswa yang belajar menggunakan model pembelajaran Discovery Learning adalah 3,06 sedangkan pada kelompok siswa yang belajar menggunakan cara pembelajaran konvensional adalah 2,77. Berdasarkan hasil uji $t$ diperoleh $\mathbf{t}_{\text {hitung }}=\mathbf{2 , 9 4 8}>\mathbf{1 , 9 9 8}\left(\mathbf{t}_{63 ; 05}\right)$. Ini menunjukkan adanya perbedaan prestasi belajar fisika antara kelompok siswa yang dibelajarkan dengan menggunakan model pembelajaran Discovery Learning dan siswa yang dibelajarkan dengan cara pembelajaran konvensional. Selanjutnya dari hasil rerata skor post test dapat diketahui bahwa prestasi belajar fisika siswa pada kelas eksperimen lebih tinggi daripada prestasi belajar pada kelas kontrol.

Perbedaan prestasi belajar pada kelas ekperimen dan kelas kontrol disebabkan oleh beberapa aktivitas berbeda yang terjadi pada kedua kelas selama proses pembelajaran berlangsung. Prestasi belajar fisika siswa yang lebih tinggi pada saat dibelajarkan dengan model Discovery Learning dibandingkan dengan pembelajaran konvensional disebabkan beberapa faktor yaitu:

3.2.1. Pada kegiatan inti pembelajaran, siswa yang dibelajarkan dengan model Discovery Learning lebih dapat mengeksplorasi materi dan menemukan konsep sendiri. Kegiatan inti pembelajaran lebih bervariasi, yaitu dengan praktikum, diskusi, presentasi, tanya jawab, dan membaca literatur. Dengan metode belajar tersebut, siswa akan lebih banyak berpikir dan menemukan materi fisika yang dipelajarinya. Hal ini sesuai dengan yang Bruner (dalam Dahar 1988: 125), berusaha sendiri untuk mencari pemecahan masalah serta pengetahuan yang menyertainya, menghasilkan pengetahuan yang benar-benar bermakna.

3.2.2. Pada kegiatan inti pembelajaran, siswa yang dibelajarkan secara konvensional menerima semua informasi dari guru. Kegiatan inti pembelajaran cenderung monoton karena guru sering memberi penjelasan dan contoh soal. Hal tersebut menyebabkan siswa kurang dapat memaknai materi yang dipelajarinya.

3.2.3. Pada akhir pembelajaran, siswa yang dibelajarkan dengan model Discovery Learning harus mengulas kembali pertanyaan yang diajukan di awal, menyimpulkan dan merefleksi pembelajaran sesuai tujuan pembelajaran. Siswa juga diminta menerapkan konsep yang telah mereka temukan ke dalam soal. Siswa diminta aktif mengerjakan soal di depan kelas, kemudian siswa menerima reward.

3.2.4.Pada akhir pembelajaran, siswa yang dibelajarkan secara konvensional diberi tugas yang harus dikumpulkan pada pertemuan berikutnya. Tugas berupa soalsoal latihan suhu dan kalor. Banyak siswa kurang dapat memahami cara 
mengerjakan soal, karena siswa tergantung pada penjelasan contoh soal yang diberikan guru.

Hasil analisis menunjukkan pembelajaran dengan model Discovery Learning berpengaruh pada prestasi belajar fisika siswa. Model Discovery Learning dapat meningkatkan prestasi belajar fisika siswa pada pokok bahasan suhu dan kalor. Menurut Wenning (2010) model Discovery Learning berbasis Levels of Inquiry ini membuat siswa mengembangkan keterampilan intelektual elementer yang meliputi keterampilan mengamati, merumuskan konsep, memperkirakan, menarik kesimpulan, mengkomunikasikan hasil, dan mengelompokkan hasil. Keterampilan yang dikembangkan pada model Discovery Learning berbasis Levels of Inquiry tersebut apabila dimiliki oleh siswa, maka prestasi belajar fisika siswa yang meliputi empat aspek yaitu mengingat (C1), memahami (C2), menerapkan (C3), dan menganalisis (C4) dapat ditingkatkan. Hal ini disebabkan keterampilan yang dilatihkan tersebut dapat mengasah kognitif siswa.

Berdasarkan penelitian ini, siswa yang belajar menggunakan model pembelajaran Discovery Learning memiliki prestasi belajar yang lebih tinggi daripada siswa yang belajar secara konvensional. Sesuai dengan pernyataan Balım (2009) bahwa pembelajaran dengan Discovery Learning berpengaruh lebih baik dalam meningkatkan prestasi akademik siswa dibandingkan dengan cara pembelajaran konvensional. Siswa yang belajar dengan model Discovery Learning akan melalui serangkaian tahap pembelajaran penemuan terstruktur sehingga siswa dapat lebih mengingat, memahami, menerapkan, dan menganalisis materi yang dipelajari. Hal ini sesuai dengan Wenning (2011) yang menyatakan bahwa tahapan pembelajaran yang sistematis, akan membantu siswa mengembangkan kemampuan berpikir secara mandiri daripada pembelajaran yang hanya mendengarkan atau membaca saja.

Kelebihan model Discovery Learning adalah dapat meningkatkan prestasi belajar siswa. Namun, dalam penerapannya model pembelajaran Discovery Learning juga memiliki kekurangan, yaitu:

3.2.4.1.Penerapan model pembelajaran Discovery Learning membutuhkan persiapan, pelaksanaan, dan evaluasi yang rumit dan menyita waktu. Pada setiap pertemuan, terdapat kegiatan praktikum yang disertai dengan pembahasan hasil praktikum agar siswa mampu menemukan konsep secara kualitatif. Ini membuat guru harus mempersiapkan alat dan bahan praktikum sebaik mungkin.

3.2.4.2.Siswa belum terbiasa dengan model pembelajaran Discovery Learning, sehingga untuk menemukan konsep - konsep fisika tentang suhu dan kalor masih diperlukan bimbingan guru.

\section{Simpulan}

\subsection{Kesimpulan}

Berdasarkan hasil analisis data dan pembahasan, diperoleh kesimpulan sebagai berikut: (1) Prestasi belajar fisika siswa yang dibelajarkan dengan model Discovery Learning lebih tinggi daripada siswa yang belajar dengan cara konvensional. Pada 
kegiatan inti pembelajaran, siswa yang dibelajarkan dengan model Discovery Learning lebih dapat mengeksplorasi materi dan menemukan konsep fisika sendiri. Sedangkan siswa yang dibelajarkan secara konvensional menerima semua informasi dari guru. (2) Model pembelajaran Discovery Learning berpengaruh terhadap prestasi belajar fisika siswa kelas X SMAN 02 Batu. Hal ini disebabkan keterampilan yang dilatihkan saat menggunakan model Discovery Learning dapat mengasah kognitif siswa. Model Discovery Learning berbasis Levels of Inquiry ini membuat siswa mengembangkan keterampilan intelektual elementer yang meliputi keterampilan mengamati, merumuskan konsep, memperkirakan, menarik kesimpulan, mengkomunikasikan hasil, dan mengelompokkan hasil (Wenning, 2010).

\subsection{Saran}

Berdasarkan penelitian yang telah dilakukan, terdapat beberapa saran yang diberikan, yaitu: (1) Bagi guru mata pelajaran fisika, model pembelajaran Discovery Learning dapat digunakan sebagai salah satu alternatif dalam pembelajaran fisika di kelas karena dapat meningkatkan prestasi belajar siswa. Sebelum diterapkan model pembelajaran Discovery Learning untuk pembelajaran Fisika di dalam kelas, guru sebaiknya memberikan pengarahan tentang alur pembelajaran yang akan dilakukan oleh siswa dan hal - hal teknis mengenai cara mengerjakan lembar kerja siswa. (2) Salah satu kelemahan dalam penelitian ini adalah pada tahap verification, siswa kesulitan mencocokan antara konsep yang telah mereka temukan dan konsep yang belum mereka temukan setelah melewati serangkaian proses diskusi dan presentasi. Oleh karena itu untuk penelitian selanjutnya dibutuhkan penjelasan atau penguatan dari guru setiap berakhirnya proses diskusi dan presentasi oleh siswa, supaya konsep yang ditemukan siswa semakin dapat dipahami.

\section{Daftar Rujukan}

Balım, A. G. (2009). The Effects of Discovery Learning on Students' Success and Inquiry Learning Skills. Eurasian Journal of Educational Research (EJER), (35).

Dahar, R.W. (1989). Teori-Teori Belajar. Jakarta: Erlangga.

Kebudayaan, K. P. (2013). Materi Pelatihan Guru Implementasi Kurikulum 2013. Nuh, M.(2013). Kurikulum.

Kebudayaan, K. P. (2014). Salinan Lampiran Peraturan Menteri Pendidikan dan Kebudayaan RI No. 59 tahun 2014 tentang Kerangka Dasar dan Struktur Kurikulum.

Sugiyono. (2012). Statistika untuk penelitian. Bandung: Alfabeta

Trianto. (2010). Mengembangkan Model Pembelajaran Tematik. Jakarta: PT Prestasi Pustakaraya.

Wenning, C. J. (2005). Levels of inquiry: Hierarchies of pedagogical practices and inquiry processes. In J. Phys. Teach. Educ. Online.

Wenning, C. J. (2010), Levels of Inquiry: Using Inquiry Spectrum Learning Sequences to Teach Science, Journal of Physics Teacher Education Online, 5(4), 11-20.'

Wenning, C. J. (2011), Experimental Inquiry in Introductory Physics Courses, Journal of Physics Teacher Education Online, 6(2), 2-8. 